\title{
Effects of perioperative hypothermia and reactive oxygen species in the healing of colonic anastomosis in rats ${ }^{1}$
}

\author{
João Carlos Costa de Oliveira', Camila Helena de Oliveira ${ }^{\mathrm{II}}$, Henrique Eduardo de Oliveira ${ }^{\mathrm{II}}$, Aline Pereira ${ }^{\mathrm{III}}$, Marcelo \\ Maraschin $^{\text {IV }}$, Armando José d'Acâmporav \\ DOI: http://dx.doi.org/10.1590/S0102-86502014001800008 \\ ${ }^{\mathrm{I}} \mathrm{PhD}$, Associate Professor, Department of Surgery, Federal University of Santa Catarina (UFSC), Florianopolis-SC, Brazil. Conception and design of \\ the study, acquisition and interpretation of data, technical procedures, manuscript writing.

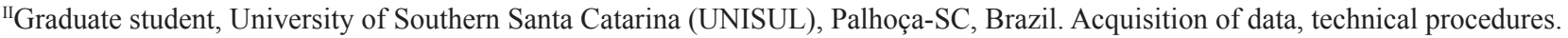

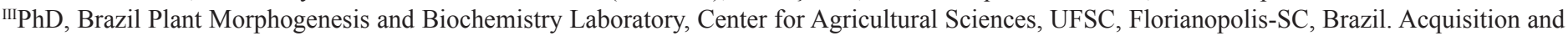 \\ interpretation of data, technical procedures. \\ ${ }^{\text {IV }} \mathrm{PhD}$, Associate Professor, Brazil Plant Morphogenesis and Biochemistry Laboratory, Center for Agricultural Sciences, UFSC, Florianopolis-SC, \\ Brazil. Acquisition and interpretation of data, technical procedures, critical revision. \\ ${ }^{v} \mathrm{PhD}$, Associate Professor, Department of Surgery, UFSC, Florianopolis-SC, Brazil. Conception and design of the study, interpretation of data, critical \\ revision, final approval.
}

\section{ABSTRACT}

PURPOSE: We evaluated the hypothesis that induced perioperative hypothermia $\left(32 \pm 1^{\circ} \mathrm{C}\right)$ affects the redox balance in the tissue of colonic anastomosis in rats by modifying biochemical enzymatic and non-enzymatic markers related to oxidative stress.

METHODS: Forty-eight male Wistar rats were randomly divided into eight experimental groups of six animals each and underwent laparotomy, sigmoid section and immediate anastomosis. Four groups were operated under normothermia $\left(36 \pm 1^{\circ} \mathrm{C}\right)$, and the other four under hypothermia $\left(32 \pm 1^{\circ} \mathrm{C}\right)$. The animals were reoperated on days 3, 7 and 14 postoperatively, and two groups underwent SHAM at 3 days. From the scar tissue samples, the activity of the antioxidant enzymes superoxide dismutase (SOD) and catalase (CAT) was evaluated, and the levels of non-enzymatic markers of oxidative stress, such as reduced glutathione (GSH) and lipid peroxidation, were measured by the thiobarbituric acid reactive substances (TBARS) assay. The means were compared between groups corresponding to each day of sampling and euthanasia.

RESULTS: The hypothermic groups showed a significant reduction on the activity of SOD on day 7 postoperatively, on the activity of CAT on days 7 and 14 postoperatively and on the levels of GSH on day 7 postoperatively. The level of lipid peroxidation was increased in the hypothermia group on day 7 postoperatively and decreased on day 14 compared with the normothermic groups.

CONCLUSION: Perioperative hypothermia reduced the activity of the antioxidant enzymes catalase and superoxide dismutase, glutathione levels and increased lipid peroxidation in the scar tissue of colonic anastomoses in rats.

Key words: Anastomosis, Surgical. Hypothermia. Oxidative Stress. Reactive Oxygen Species. Rats. 


\section{Introduction}

The colon is the most vulnerable region of the gastrointestinal tract to anastomotic dehiscence ${ }^{1-4}$, a much feared complication that presents serious and potentially lethal consequences $^{2,3}$. Perioperative hypothermia is associated with detrimental effects to the patient, increasing the rate of operative complications and post-operative anesthetic ${ }^{4}$. The incidence of surgical site infection increases in patients undergoing perioperative hypothermia compared with those under normothermia ${ }^{5}$. Hypothermia impairs immune function ${ }^{6}$ and also reduces the partial pressure of oxygen at the tissue surgical site $^{7}$. When the intestine is cut and the tissues are damaged, a complex and organized sequence of cellular and molecular events is triggered, represented by the proliferation of repair cells and the release of cytokines and growth factors, which culminate in healing. This entire process can be influenced by external factors ${ }^{8}$.

Large amounts of reactive oxygen species (ROS) are produced in the damaged tissue and are inflamed by NADPH oxidase, an enzyme complex that is expressed at high levels, particularly in inflammatory cells. This phenomenon has been described as the "respiratory burst". After the activation of NADPH oxidase, the cells produce superoxide, a highly reactive free radical. This radical is quickly dismuted to hydrogen peroxide $\left(\mathrm{H}_{2} \mathrm{O}_{2}\right)$ and water, a process that is facilitated by the enzyme superoxide dismutase (SOD). Although $\mathrm{H}_{2} \mathrm{O}_{2}$ is not a radical, it may cause serious cell damage due to the generation of hydroxyl radicals in the presence of iron ions or copper ions (Fenton reaction) ${ }^{9}$. The injuries from stress or trauma or the inflammatory response may be important sources that generate these radicals ${ }^{10}$. The body's defense cells may also be important sources of oxidative stress and in the release of important enzymes related against free radicals, such as the antioxidant enzymes catalase (CAT), glutathione peroxidase (GPx), glutathione $\mathrm{S}$ transferase (GST) and superoxide dismutase (SOD) ${ }^{11}$. SOD and CAT act as the primary line of defense in the detoxification of free radicals. Finally, one of the major toxic effects of excessive ROS is damage to the cell membrane by the process of lipid peroxidation, which can be monitored by the amount of thiobarbituric acid (TBARS) ${ }^{11}$. If the detoxification and neutralization of ROS are insufficient or if the ROS are produced in excess, oxidative stress occurs, representing an imbalance between the amount of free radicals and antioxidant defenses ${ }^{9}$. In this study, we evaluated the hypothesis that perioperative hypothermia impairs the balance between antioxidant defenses and production of ROS in the tissue of colonic anastomosis in rats by a change in the antioxidant enzyme activity due to excess ROS tissue, which causes increased lipid peroxidation of cell membranes and deleterious effects to the healing process.

\section{Methods}

The Ethics Committee on Animal Use (CEUA) of the UFSC approved the study, with the case registered under number: 23080.019985/2010-80.

The animals used in this study included 48 male rats of the species Rattus norvegicus, Wistar strain, from the Central Animal Facility of the Federal University of Santa Catarina (UFSC). The animals were aged between 180-220 days with weights ranging between 360 and $480 \mathrm{~g}$. They were acclimated for seven days at the Laboratory of Experimental Surgery and Operative Technique of the UFSC, receiving food and water ad libitum, with a standardized light-dark cycle of 12 hours at $22^{\circ} \mathrm{C} \pm$ $2^{\circ} \mathrm{C}$ and humidity between 50 and $60 \%$.

All procedures were performed under general anesthesia using a combination of intramuscular ketamine $(9 \mathrm{mg} / 100 \mathrm{~g}$ body weight) and thiazine (1.25 mg/100 g body weight). A 2-cm laparotomy was performed under aseptic conditions. The sigmoid colon was identified and sectioned with straight scissors, $2 \mathrm{~cm}$ above the peritoneal reflection. Immediately afterwards, an end-to-end anastomosis was performed with eight separate stitches of 6-0 polypropylene (Ethicon ${ }^{\circledR}$, Somerville, NJ) in the extramucosal plane. The abdominal wall was closed in two planes, and the aponeuroses and skin were closed with continuous 4-0 polypropylene sutures (Ethicon ${ }^{\circledR}$, Somerville, NJ).

At pre-determined times (three, seven and 14 days) reoperations were performed under the same conditions of the initial surgery. The anastomosis was identified and the sigmoid colon containing the anastomosis was resected for analysis, with the abdominal wall closed as described in the first surgery. Then, a 1-cm segment containing the anastomosis was removed and sectioned longitudinally into four identical fabric strips that were $1 \mathrm{~cm}$ long, each containing a portion of the anastomosis. The fragment for this study was stored in a freezer at $-80{ }^{\circ} \mathrm{C}$ until the analyses of the oxidative stress enzymes and TBARS. While still anesthetized, the animals were killed with a lethal dose of intracardiac potassium chloride.

\section{Groups}

The animals were randomized into two groups, one with hypothermia and the other with normothermia, and each 
group was divided into four groups of six animals each, which were numbered according to the time in days post-surgery of the reoperation and the euthanasia: (1) normothermia and three days;

(2) hypothermia and three days; (3) normothermia and seven days;

(4) hypothermia and seven days; (5) normothermia and 14 days;

(6) hypothermia and 14 days; (7) SHAM, normothermia and three days and (8) SHAM, hypothermia and three days (Figure 1).

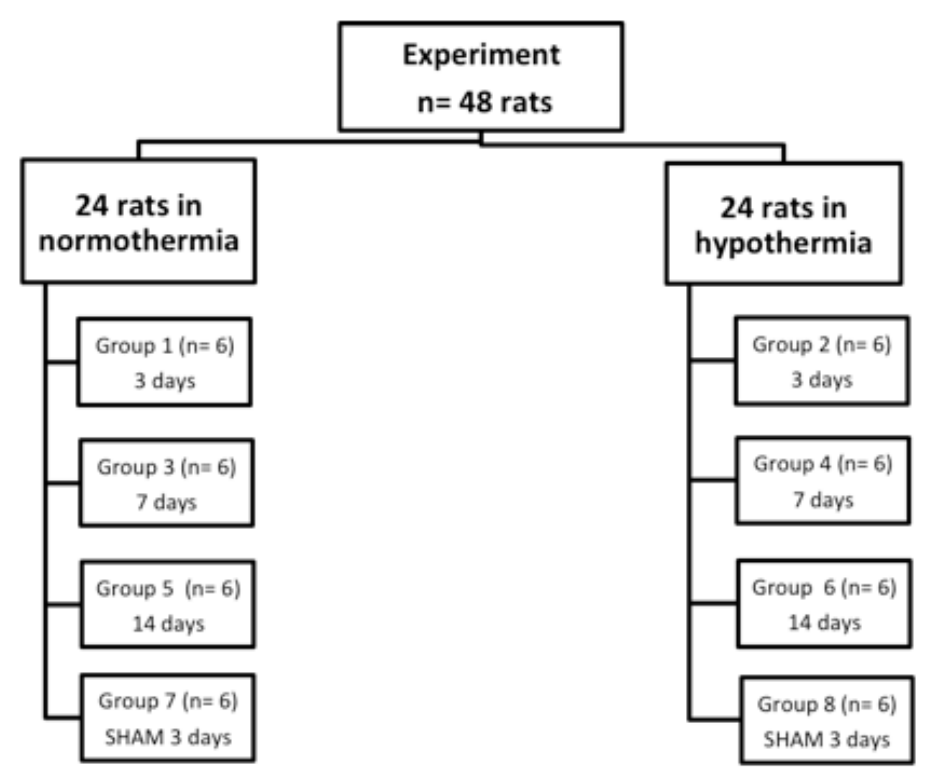

FIGURE 1 - Division of study group.

The animals in the groups with hypothermia had their core temperature decreased to $32^{\circ} \mathrm{C} \pm 1{ }^{\circ} \mathrm{C}$ using plastic bags with ice gel on the chest, maintaining hypothermia for one hour during the surgery, and were then heated with heat from an infrared lamp up to $37^{\circ} \mathrm{C}$. The animals in the normothermia groups had their temperature maintained at $36 \pm 1^{\circ} \mathrm{C}$ with the use of an infrared lamp. The temperature was measured with a digital thermometer $\left(\mathrm{Getec}^{\circledR}\right.$, Sao Paulo, Brazil) inserted into the rectum, before and during the procedure and until the full recovery of the animal, with temperature measurements every five minutes. The temperature was maintained at the desired level in each group with the approach or separation of the sources of heat and cold from the animal body, as needed.

\section{Markers of oxidative stress}

The analysis of SOD as performed by the oxidation of adrenaline with the formation of superoxide anion $\left(\mathrm{O}_{2}^{-}\right)$and adrenochrome pink. The formation of $\mathrm{O}_{2}{ }^{-}$is delayed by the enzyme SOD present in the sample. The samples were assayed in triplicate, and the values are expressed in U SOD/mg protein ${ }^{1,12}$.
For the analysis of catalase activity, the decomposition rate of hydrogen peroxide $\left(\mathrm{H}_{2} \mathrm{O}_{2}\right)$ at a wavelength of $240 \mathrm{~nm}$ was observed. The samples were analyzed in triplicate, and the values are expressed in mmol. $\mathrm{min}^{-1} . \mathrm{mg}$ protein ${ }^{1,13}$.

The content of reduced glutathione (GSH) was obtained by assessing the concentration of small thiols ( $\mathrm{SH}$ ) immediately after obtaining the tissue homogenates in an acidic solution to prevent their oxidation. The quantification of reduced glutathione is based on the reaction of SH with dithionitrobenzoic acid (DTNB) to form the thiolate anion (TNB), which has a yellow color, measured at $412 \mathrm{~nm}$. The analyses were performed in triplicate, and the values are expressed in mM.mg protein ${ }^{1,14}$.

To determine the level of lipid peroxidation, thiobarbituric acid reactive substances (TBARS) were measured. Samples of scar tissue $(35 \mathrm{mg}$ ) were homogenized with $1600 \mu \mathrm{L}$ of $1.1 \%$ phosphoric acid. This analysis is based on the reaction of one molecule of malondialdehyde (MDA) with two molecules of thiobarbituric acid (TBA) and the elimination of two water molecules, forming a pigment with a pink color with maximum absorptions at 532 and $600 \mathrm{~nm}$. The analyses were performed in triplicate ${ }^{15}$. The level of lipid peroxidation was calculated as follows: TBARS (nmol.mg protein $\left.{ }^{-1}\right)=\{[$ Sample Absorbance $\left(\mathrm{A}_{532}-\mathrm{A}_{600}\right)$. dilution] $\left./ 156\right\} / \mathrm{mg}$ protein.

\section{Statistical analysis}

All results were subjected to the calculation of means and standard deviations. The means were compared using the unpaired two-tailed $t$ test. A $p$ value less than 0.05 was considered to be statistically significant. All statistical analyses and the creation of the graphics were performed using the program Graph Pad Prism ${ }^{\circledR}$ version 2.1 for Windows (Graph Pad Software, San Diego, CA).

\section{Results}

No animals died during the study. No sign of anastomotic leakage was identified in the evaluated colonic segments. The mean weight loss in the 3-day groups was higher in the

hypothermia group but was higher at seven days in the normothermia group. The 14-day groups showed a weight gain with respect to the first surgery, being higher in the normothermic group, but these results were not significant. 


\section{Superoxide dismutase enzyme}

The measurements of SOD activity showed no significant differences between groups 1 and 2 (three days) with means of $0.4482( \pm 0.08044)$ and $0.9604( \pm 0.1940) \mathrm{U} \mathrm{SOD} / \mathrm{mg}$ protein, respectively. The same result occurred with the two SHAM groups, 7 and 8, with no significant differences. In the 7 day groups, the means of groups 3 and 4 were significantly different, with outcomes of $1.374( \pm 0.2129)$ and $0.6476( \pm$ $0.04539) \mathrm{U} \mathrm{SOD} / \mathrm{mg}$ of protein $(\mathrm{p}=0.0076)$, respectively. In the 14 day groups, the differences between the means of groups 5 and 6 were $1.444( \pm 0.1206)$ and $1,363( \pm 0.06365) \mathrm{U}$ SOD/ $\mathrm{mg}$ of protein, respectively, without statistical significance (Figure 2).

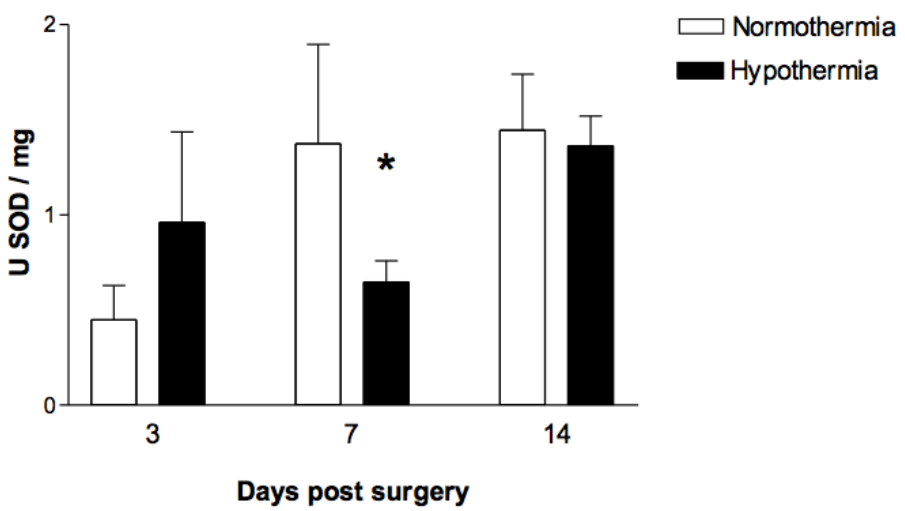

FIGURE 2 - Superoxide dismutase (SOD) activity in the tissue of colonic anastomosis in $\mathrm{U} \mathrm{SOD} / \mathrm{mg}$ protein, with respect to the days post-surgery and the groups: groups 1 and 2 (three days), groups 3 and 4 (seven days) and groups 5 and 6 (14 days). ${ }^{*} \mathrm{p}<0.05$.

\section{Catalase enzyme}

The means of the activity from the catalase enzyme in the colonic anastomoses were similar when comparing groups three days post-surgery, groups 1 and 2, with the results of 1.116 $( \pm 0.1731) \mathrm{mM} \cdot \mathrm{min}^{-1} / \mathrm{mg}$ protein in the normothermic group and $1.163( \pm 0.1598) \mathrm{mM} \cdot \mathrm{min}^{-1} / \mathrm{mg}$ protein in the hypothermic group. The SHAM groups, 7 and 8 , also showed no significant differences. However, the comparisons between groups 3 and 4 and between 5 and 6 showed significant mean differences. At seven days post-surgery, the normothermic and hypothermic groups had means of $1.485( \pm 0.1216)$ and $0.8816( \pm 0.08559)$ $\mathrm{mM} \cdot \mathrm{min}^{-1} / \mathrm{mg}$ protein, respectively $(\mathrm{p}=0.0023$ ). At 14 days post-surgery, the normothermic and hypothermic groups showed results of $2.612( \pm 0.2186)$ and $1.439( \pm 0.07558)$ $\mathrm{mM} \cdot \mathrm{min}^{-1} / \mathrm{mg}$ protein, respectively $(\mathrm{p}=0.0005)($ Figure 3$)$.

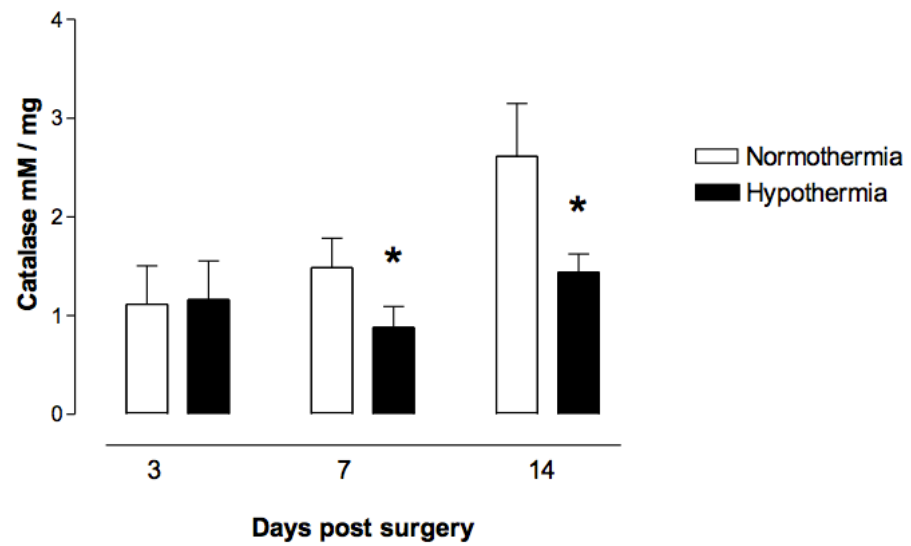

FIGURE 3 - Catalase activity in the tissue of colonic anastomosis in $\mathrm{mM} / \mathrm{mg}$, with respect to the days post-surgery and the groups: groups 1 and 2 (three days), groups 3 and 4 (seven days) and groups 5 and 6 (14 days). ${ }^{*} \mathrm{p}<0.05$.

\section{Glutathione (GSH)}

The amounts of GSH scar tissue of colonic anastomoses also showed significantly reduced values in the hypothermia group compared with the normothermic group at 7 days post-surgery. Groups 3 and 4 had $0.5136( \pm 0.0352)$ and $0.3542( \pm 0.0108) \mathrm{mM} /$ $\mathrm{mg}$ protein, respectively $(\mathrm{p}=0.0015)$. The other comparisons were not significantly different, i.e., among the 3 day, 14 day and SHAM groups. Groups 1 and 2 had $0.3985( \pm 0.0215)$ and $0.4329( \pm 0.01985)$ $\mathrm{mM} / \mathrm{mg}$ protein, respectively, and groups 5 and 6 had $0.4434( \pm$ $0.03619)$ and $0.5092( \pm 0.06636) \mathrm{mM} / \mathrm{mg}$ protein (Figure 4).

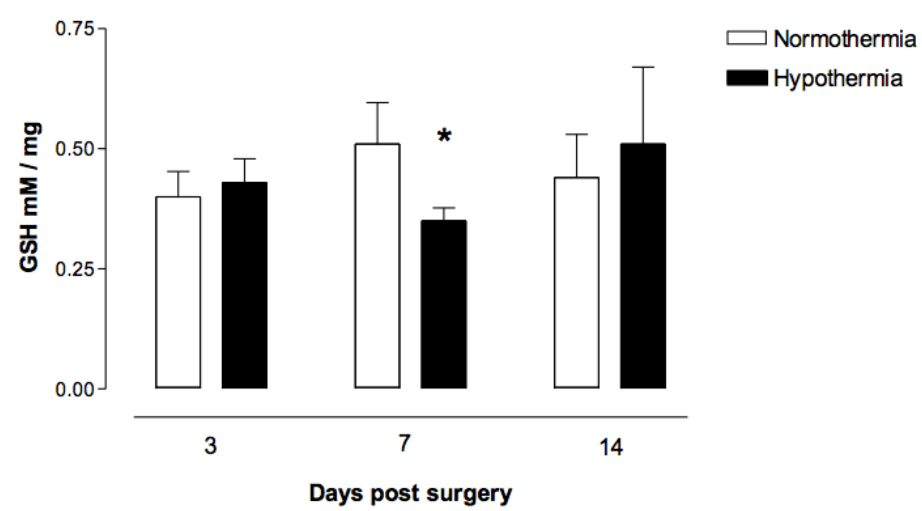

FIGURE 4 - Levels of reduced glutathione (GSH) in the tissue of colonic anastomosis in $\mathrm{mM} / \mathrm{mg}$, with respect to the days postsurgery and the groups: groups 1 and 2 (three days), groups 3 and 4 (seven days) and groups 5 and 6 (14 days). ${ }^{*} \mathrm{p}<0.05$.

\section{Level of lipid peroxidation (TBARS)}

The measurement of lipid peroxidation by TBARS showed higher levels in the hypothermic groups of the three and seven day rats compared with their normothermic counterparts. However, at 14 days post-surgery in group 6, hypothermia reduced 
the TBARS level, which was lower than that of group 5 under normothermia. The SHAM groups 7 and 8 were not significantly different. Groups 1 and 2 had $44.82( \pm 4.91)$ and $50.04( \pm 3.35)$ $\mathrm{nmol} / \mathrm{mg}$ protein, respectively, with no significant difference. Groups 3 and 4 had $40.07( \pm 5.32)$ and $60.54( \pm 3.58) \mathrm{nmol} / \mathrm{mg}$ protein, respectively $(\mathrm{p}=0.0097)$. Groups 5 and 6 had 53.24 $( \pm 3.78)$ and $34.24( \pm 2.54) \mathrm{nmol} / \mathrm{mg}$ protein, respectively $(\mathrm{p}=$ 0.0019) (Figure 5).

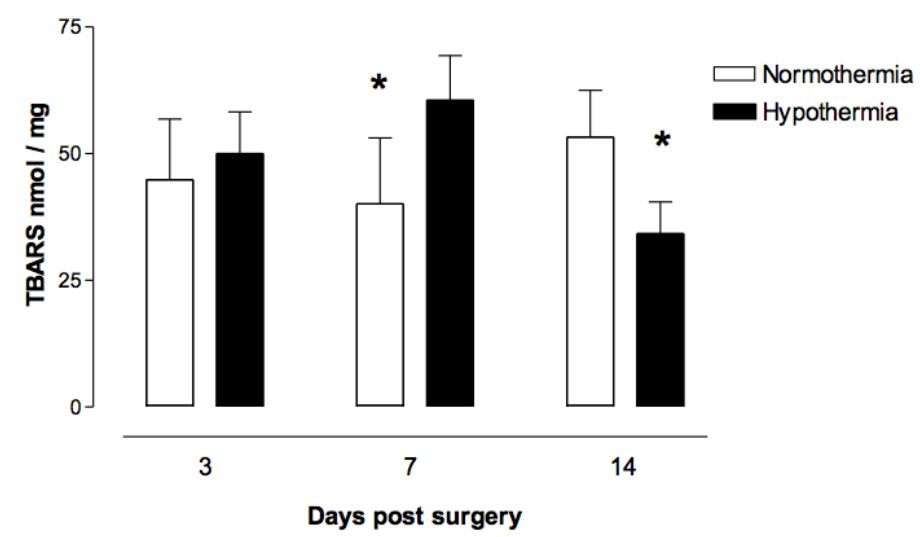

FIGURE 5 - Content of thiobarbituric acid reactive substances (TBARS) in the tissue of colonic anastomosis in $\mathrm{nM} / \mathrm{mg}$, with respect to the days post-surgery and the groups: groups 1 and 2 (three days), groups 3 and 4 (seven days) and groups 5 and 6 (14 days). ${ }^{*} \mathrm{p}<0.05$.

\section{Discussion}

Healing requires a fine balance between the positive and deleterious effects of ROS, a group of extremely potent molecules with power that can limit the rate of tissue regeneration ${ }^{16}$. The overproduction of ROS is associated with tissue injury, the generation of many diseases and the destruction of healthy tissue stroma ${ }^{16,17}$. Excess ROS damage cell membranes by lipid peroxidation and also damage deoxyribonucleic acid (DNA) and proteins. The attack of ROS on DNA breaks the strands and alters the normal process of translation and transcription, altering gene expression and DNA replication and inducing apoptosis ${ }^{18}$. Proteins may also be targets of ROS; for example, oxidation disrupt protein receptors, affects enzymatic functions and interrupts signal transduction pathways ${ }^{17,19}$. The reduction of lipid peroxidation and increased GSH levels in the tissue of colon anastomosis in rats is associated with the increased hydroxyproline content of the tissues, which can increase the burst pressure of the anastomosis ${ }^{20}$. Malonaldehyde (MDA), which is a product of lipid peroxidation, shows increased levels in delayed wound healing, resulting from the use of hydrocortisone in mice compared with control mice group ${ }^{21}$.

After the surgical section of the colon and immediate anastomosis, the inflammatory reaction is initiated in response to the surgical trauma, exposure of the extracellular matrix and reaction to the suture material. The inflammatory process is normal and necessary for the proper healing of the intestinal wall ${ }^{22,23}$. Perioperative hypothermia causes thermoregulatory vasoconstriction and a consequent reduction in the oxygen tension in the tissues. It also impairs immune function and the release of cytokines and growth factors, hindering the progression of inflammation and scarring ${ }^{24}$. In addition, hypothermia reduces the recruitment and function of neutrophils and the production of natural killer cells ${ }^{25}$, thereby decreasing antibody-mediated cell damage. In this study, we found that perioperative hypothermia reduced the activity of antioxidant enzymes in tissues from colonic anastomoses in rats. The activity of SOD was significantly reduced at seven days postoperatively, and catalase activity was reduced at seven and 14 days. The GSH levels were significantly reduced at seven days postoperatively. Furthermore, the lipid peroxidation, as determined by TBARS, was increased in the tissues from animals in the hypothermia groups on seven days post-surgery, and the levels only decreased by 14 days post-surgery, which already is a late phase of wound healing. Thus, we can see that perioperative hypothermia inhibits the normal detoxification of ROS at the site of colonic anastomosis healing, thus harming the healing process. The excessive production of ROS or impaired detoxification of these highly unstable molecules causes oxidative stress, which has been identified as an important factor in the pathogenesis of chronic wounds that do not heal ${ }^{26}$.

\section{Conclusion}

The perioperative hypothermia reduces the antioxidant enzymes superoxide dismutase and catalase, reduces glutathione and increases lipid peroxidation in the scar tissue of colonic anastomoses in rats.

\section{References}

1. Yarimkaya A, Apaydin B, Unal E, Karabicak I, Aydogan F, Uslu E, Erginoz E, Artis T, Eyuboglu E. Effects of recombinant human growth hormone and nandrolone phenylpropionate on the healing of ischemic colon anastomosis in rats. Dis Colon Rectum. 2003;46(12):1690-7. PMID: 14668597.

2. Alves A, Panis Y, Trancart D, Regimbeau JM, Pocard M, Valleur P. Factors associated with clinically significant anastomotic leakage after large bowel resection: multivariate analysis of 707 patients. World J Surg. 2002;26(4):499-502. doi: 10.1007/s00268-001-02564.

3. Rullier E, Laurent C, Garrelon JL, Michel P, Saric J, Parneix M. Risk factors for anastomotic leakage after resection of rectal cancer. Br J Surg. 1998;85(3):355-8. PMID: 9529492.

4. Reynolds L, Beckmann J, Kurz A. Perioperative complications of 
hypothermia. Best Pract Res Clin Anaesthesiol. 2008;22(4):645-57. PMID: 19137808.

5. Kurz A, Sessler DI, Lenhardt R. Perioperative normothermia to reduce the incidence of surgical-wound infection and shorten hospitalization. Study of wound infection and temperature group. N Engl J Med. 1996;334(19):1209-15. PMID: 8606715.

6. Beilin B, Shavit Y, Razumovsky J, Wolloch Y, Zeidel A, Bessler H. Effects of mild perioperative hypothermia on cellular immune responses. Anesthesiology. 1998;89(5):1133-40. PMID: 9822001.

7. Greif R, Akca O, Horn EP, Kurz A, Sessler DI. Supplemental perioperative oxygen to reduce the incidence of surgical-wound infection. N Engl J Med. 2000;342(3):161-7. PMID: 10639541.

8. Zubaidi A, Buie WD, Hart DA, Sigalet D. Temporal expression of cytokines in rat cutaneous, fascial, and intestinal wounds: a comparative study. Dig Dis Sci. 2010;55(6):1581-8. doi: 10.1007/ s10620-009-0931-0.

9. Houghton PJ, Hylands PJ, Mensah AY, Hensel A, Deters AM. In vitro tests and ethnopharmacological investigations: wound healing as an example. J Ethnopharmacol. 2005;100(1-2):100-7. PMID: 16040217.

10. Thomas SR, Witting PK, Drummond GR. Redox control of endothelial function and dysfunction: molecular mechanisms and therapeutic opportunities. Antioxid Redox Signal. 2008;10(10):171365. doi: 10.1089/ars.2008.2027.

11. Ciencewicki J, Trivedi S, Kleeberger SR. Oxidants and the pathogenesis of lung diseases. J Allergy Clin Immunol. 2008;122(3):456-68; quiz 69-70. doi: 10.1016/j.jaci.2008.08.004.

12. Misra HP, Fridovich I. The role of superoxide anion in the autoxidation of epinephrine and a simple assay for superoxide dismutase. J Biol Chem. 1972;247(10):3170-5. PMID: 4623845.

13. Aebi H. Catalase in vitro. Methods Enzymol. 1984;105:121-6. PMID: 6727660.

14. Beutler E, Duron O, Kelly BM. Improved method for the determination of blood glutathione. J Lab Clin Med. 1963;61:882-8. PMID: 13967893.

15. Hermes-Lima M, Willmore WG, Storey KB. Quantification of lipid peroxidation in tissue extracts based on $\mathrm{Fe}(\mathrm{III}) x y l e n o l$ orange complex formation. Free Radic Biol Med. 1995;19(3):271-80. PMID: 7557541.

16. Bryan N, Ahswin H, Smart N, Bayon Y, Wohlert S, Hunt JA. Reactive oxygen species (ROS)--a family of fate deciding molecules pivotal in constructive inflammation and wound healing. Eur Cell Mater. 2012;24:249-65. PMID: 23007910.

17. Magder S. Reactive oxygen species: toxic molecules or spark of life? Crit Care. 2006;10(1):208. PMID: 16469133.

18. Szabo C, Zingarelli B, O'Connor M, Salzman AL. DNA strand breakage, activation of poly (ADP-ribose) synthetase, and cellular energy depletion are involved in the cytotoxicity of macrophages and smooth muscle cells exposed to peroxynitrite. Proc Natl Acad Sci USA. 1996;93(5):1753-8. PMID: 8700830.

19. Ischiropoulos H, Zhu L, Chen J, Tsai M, Martin JC, Smith CD, Beckman JS. Peroxynitrite-mediated tyrosine nitration catalyzed by superoxide dismutase. Arch Biochem Biophys. 1992;298(2):431-7. PMID: 1416974.
20. Aytekin FO, Teke Z, Aydin C, Kabay B, Yenisey C, Sacar S, Demir EM, Tekin K. Effects of a membrane-permeable radical scavenger, Tempol, on healing of colonic anastomoses in the cecal ligation and puncture model of polymicrobial sepsis in rats. Am J Surg. 2007;193(6):723-9. PMID: 17512284.

21. Gupta A, Singh RL, Raghubir R. Antioxidant status during cutaneous wound healing in immunocompromised rats. Mol Cell Biochem. 2002;241(1-2):1-7. PMID: 12482019.

22. Enoch S, Leaper DJ. Basic science of healing. Surgery. 2005;23(2):37-42. doi: 10.1383/surg.23.2.37.60352.

23. Thornton FJ, Barbul A. Healing in the gastrointestinal tract. Surg Clin North Am. 1997;77(3):549-73. PMID: 9194880

24. Torossian A, Ruehlmann S, Middeke M, Sessler DI, Lorenz W, Wulf $\mathrm{HF}$, Bauhofer A. Mild preseptic hypothermia is detrimental in rats. Crit Care Med. 2004;32(9):1899-903. PMID: 15343019.

25. Cheng YS, Yin FH, Foundling S, Blomstrom D, Kettner CA. Stability and activity of human immunodeficiency virus protease: comparison of the natural dimer with a homologous, single-chain tethered dimer. Proc Natl Acad Sci USA. 1990;87(24):9660-4. PMID: 2263618.

26. Schafer M, Werner S. Oxidative stress in normal and impaired wound repair. Pharmacol Res. 2008;58(2):165-71. doi: 10.1016/j. phrs.2008.06.004.

\section{Correspondence:}

João Carlos Costa de Oliveira

Rua Abílio Costa, 262

88037-150 Florianópolis - SC Brasil

Tel.: (55 48)3234-1258

Fax: (55 48)2108-8888

j.oliveira@ufsc.br.

Received: June 23, 2014

Review: Aug 25, 2014

Accepted: Sep 24, 2014

Conflict of interest: none

Financial source: none

${ }^{1}$ Research performed at Laboratory of Technique and Experimental Surgery, Department of Surgery and Laboratory of Pathology, University Hospital, Federal University of Santa Catarina (UFSC), Florianopolis-SC, Brazil. 